\title{
Del lustre a la penuria. La cofradía del Santísimo Sacramento, Salta (Argentina). Primera mitad del siglo XIX
}

\author{
Victor Enrique Quinteros* \\ Recibido: 6 de agosto de 2020 \\ Dictaminado: 20 de octubre de 2020 \\ Aceptado: 30 de noviembre de 2020
}

\section{RESUMEN}

En el presente artículo nos proponemos abordar el estudio de algunas de las características del proceso de secularización en la ciudad de Salta mediante el estudio de caso de la cofradía del Santísimo Sacramento. Nos interesa reconstruir la trayectoria de esta asociación religiosa y dar cuenta del conjunto de cambios que experimentó durante el transcurso de la primera mitad del siglo XIX. Para ello nos centraremos en el análisis de sus autoridades y cargos de gobierno; composición; bienes y recursos económicos; y algunas características de sus actividades religiosas. Trabajaremos principalmente con el "Libro" de la referida cofradía que contiene los registros de asientos de sus hermanos y el detalle de los balances contables efectuados en el período delimitado. Nuestra investigación nos permitirá observar el derrotero de una corporación de origen

* Facultad de Humanidades, Universidad Nacional de Salta, Salta, Argentina. Correo electrónico: enriquequinteros84@gmail.com.

ORCID: https://orcid.org/ 0000-0002-0661-9803 
colonial y las características que su fisonomía adquirió en el tránsito de un régimen de cristiandad a una modernidad religiosa.

Palabras clave: Cofradias y hermandades, siglo XIX, secularización, Estado, Iglesia.

\title{
From lustre to hardship. The Confraternity of the Blessed Sacrament, Salta (Argentina), first half of the 19th century
}

\begin{abstract}
In this article we propose to address the study of some of the characteristics of the secularization process in the city of Salta through the case study of the Confraternity of the Blessed Sacrament. We are interested in reconstructing the trajectory of this religious association and to give an account of the set of changes it experienced during the first half of the 19th century. To do so, we will focus on the analysis of its authorities and government positions; composition; assets and economic resources; and some characteristics of its religious activities. We will work mainly with the "Book" of the referred brotherhood that contains the records of entries of its brothers and the detail of the accounting balances made in the delimited period. Our research will allow us to observe the course of a corporation of colonial origin and the characteristics that its physiognomy acquired in the transition from a regime of Christianity to a religious modernity.

Key words: Confraternities and brotherhoods, 19th century, secularization, State, Church.
\end{abstract}

\section{INTRODUCCIÓN}

$\mathrm{D}$ urante la primera mitad del siglo XIX las cofradías y hermandades religiosas de origen colonial (alojadas todavía en el seno de los diversos templos de la ciudad) experimentaron una serie de transformaciones que propiciaron la reconfiguración de su fisonomía. Cambios que se vincularon más con las modificaciones que operaron en el ámbito de las prácticas religiosas que con el alcance de programas liberales/anticlericales orientados a disminuir el poder de las corporaciones eclesiásticas como sucediera en otros nacientes Estados americanos. $^{1}$

1 Véase: Palomo Infante, “Tiempos de secularización: iglesia y cofradías en Chiapas a partir de 1856”, pp. 153-172; González García, "Desintegración de bienes de cofradías y de fondos píos en Costa Rica, 1805-1845”, pp. 279-303; Gudmundson, "La expropiación de los bienes 
Será éste, entonces, el período en el que algunas de las cofradías y hermandades sobrevivirán agónicamente, adaptándose a las condiciones impuestas por el nuevo orden en construcción y a las necesidades de una feligresía que fue desarrollando nuevas prácticas y vínculos para con sus referentes sagrados. Otras, por el contrario, dejarán de existir como consecuencia de su relativa decadencia expresada ya hacia finales del siglo XVIII.

Un caso paradigmático es el de la cofradía del Santísimo Sacramento fundada en el año de 1627 en la iglesia matriz salteña. Desde sus orígenes se constituyó en una de las principales instancias de sociabilidad promovida por las autoridades civiles y eclesiásticas competentes. En las postrimerías del período colonial gozaba todavía de notoria prosperidad. Sus filas se componían de numerosos miembros de la élite local, entre ellos, los descendientes de los beneméritos primeros pobladores y un importante contingente de los prósperos comerciantes foráneos avecindados en la ciudad por aquel entonces. En ella convergían también, de forma minoritaria, algunos mestizos y naturales. Los aportes de esta nutrida y heterogénea feligresía permitieron que el culto dedicado a la Sagrada Forma se celebrase con cierto decoro y realce. Los recursos de la hermandad alcanzaban también para costear regularmente el pago de las misas que debían celebrarse por el bien de las almas de los cofrades difuntos.

Conforme transcurrieron las primeras décadas del siglo XIX esta favorable situación fue desmejorando de manera paulatina. Ya hacia fines de la década de 1850 la asociación sacramental, exhausta de recursos, se encontraba al borde de su extinción. Para entonces su composición también había cambiado presentando un perfil cada vez más marcadamente femenino y popular. En el presente artículo nos proponemos abordar el estudio de algunas de las características del proceso de secularización en la ciudad de Salta mediante el estudio de caso de la cofradía del Santísimo Sacramento. Nos interesa reconstruir la trayectoria de esta asociación religiosa y dar cuenta del conjunto de cambios que experimentó durante el transcurso de la primera mitad del siglo XIX. Para ello nos centraremos en el análisis de sus autoridades y cargos de gobierno; composición; bienes y recursos económicos; y algunas características de sus actividades religiosas. Trabajaremos principalmente con el "Libro" de la referida cofradía que contiene los registros de asientos de sus hermanos y el detalle de los balances contables efectuados en el período delimitado. Nuestra investigación nos permitirá observar el derrotero de una corporación de origen colonial y las características que su fisonomía adquirió en el tránsito de un régimen de cristiandad a una modernidad religiosa. 
Las cofradías y hermandades católicas han sido ampliamente estudiadas para el espacio rioplatense. Numerosas son las investigaciones que se encargaron de dar cuenta, desde diversas perspectivas de análisis, de su compleja imbricación en las sociedades de Antiguo Régimen, remarcando, entre otros aspectos, su gravitación en la consolidación del cristianismo y sus cultos, en el forjamiento de identidades culturales, en el mantenimiento del orden colonial y en la reproducción de sus jerarquías y relaciones de poder. Diversos son también los estudios que centraron su atención en los imaginarios y representaciones que se fraguaban, en parte, en el seno de estas corporaciones y que dotaban de sentido las prácticas y acciones de la feligresía devota, su propia intimidad y su relación con lo colectivo y con lo sobrenatural. ${ }^{2}$ Estas corporaciones se revelaron funcionales incluso, según se ha demostrado, para los sectores subalternos de la sociedad colonial que hicieron de ellas espacios desde donde defendieron sus propios intereses (materiales y espirituales) y resguardaron parte de su quebrantada herencia cultural. ${ }^{3}$

Debemos señalar, sin embargo, que las cofradías religiosas no han constituido un objeto de estudio privilegiado para el análisis de la denominada modernidad religiosa. Ello se debe, en parte, a la efectiva pérdida de su importancia relativa como forma asociativa frente la emergencia y proliferación, en el transcurso del siglo XIX, de novedosas experiencias como las sociedades benéficas y los círculos de obreros, entre otras. Por este motivo, también, se han concebido como vestigios de un orden ya caduco aun cuando en algunas ciudades, al menos hasta la década de 1850 , hayan constituido las principales instancias asociativas para algunos sectores sociales. ${ }^{4}$

2 Véase González Fasani, “¿Qué entendemos por cofradía colonial?: una aproximación a un marco teórico para su estudio", pp. 225-259; Fogelman, "Una cofradía mariana urbana y otra rural en Buenos Aires a fines del período colonial", pp. 179-207; Barral, "Iglesia, poder y parentesco en el mundo rural colonial. La cofradía de Ánimas benditas del Purgatorio, Pilar. 1774", pp. 15-56; Cruz, "Autoridades socio-religiosas en el antiguo régimen. Los mayordomos de cofradías en el Jujuy colonial", pp. 35-56; Cruz, "Esclavos españoles, indios y negros: notas para el estudio de las relaciones interétnicas en las cofradías religiosas del norte del Virreinato del Río de la Plata", pp. 449-458; Estruch, "Fundar, gobernar y rezar. Una aproximación a los vínculos entre sociedad, política y religión en el Jujuy colonial. 1665-1776)”, pp. 61-78; Martínez de Sánchez, Cofradias y obras pías en Córdoba del Tucumán; Mazzoni, "Cofradías como zona de contacto. Diócesis de Córdoba, fines del siglo XVIII y principios del XIX”, pp. 97-127.

3 Caretta y Zacca, "Benditos ancestros: comunidad, poder y cofradía en Humahuaca en el siglo XVIII”, pp. 51-72; Cirio, “¿Rezan o bailan? Disputas en torno a la devoción a San Baltazar por los negros en el Buenos Aires colonial", pp. 88-100; Zanolli, "Entre la coerción, la oportunidad y la salvación. Las cofradías de indios de San Antonio de Humahuaca. Siglos XVIII y XVIII", pp. 345-369; Quinteros, "Profanando las sagradas fiestas con ritos y ceremonias gentilicias. Cofradías, poder y religiosidades. Salta, 1750-1810”, pp. 1-20.

$4 \quad$ Vagliente, "El asociativismo comparado: Buenos Aires y Córdoba en la etapa de la explosión asociativa 1850-1890”, pp. 1-14. 
La decadencia de las cofradías pareció principiar, según las clásicas consideraciones historiográficas, hacia fines del siglo xVIII, producto del amplio plan de reformas implementado por la Corona española. ${ }^{5}$ Las revisiones críticas de estos postulados, sin embargo, han brindado nuevas claves interpretativas para comprender la pervivencia de tales experiencias asociativas a través del tiempo y su dinamismo aun en contextos culturalmente distintos al de su gestación. Estas investigaciones esbozadas principalmente para el caso de México, Centroamérica y España ${ }^{6}$ y la evidencia documental con la que contamos para el espacio salteño dan cuenta, también, de que lejos de constituir resabios de una configuración sociocultural ya caduca (destinados de una u otra forma a desaparecer) las cofradías y hermandades experimentaron una suerte de modernización de su fisonomía que les permitió fortalecer el cuadro de las decimonónicas asociaciones religiosas.

Hasta el momento las problemáticas mencionadas no han sido analizadas sistemáticamente para el espacio salteño. Contamos, sin embargo, con el aporte de algunas investigaciones que se interesaron por estudiar diversas modificaciones que operaron en esta misma cofradía en el largo período de tiempo que se extiende desde fines del siglo XVIII hasta fines del siglo XIX. ${ }^{7}$ Retomaremos sus consideraciones y planteos con el fin de profundizarlos y ahondar en el estudio de las relaciones que se pueden establecer entre los nuevos caracteres que adquirieron estas asociaciones religiosas y el proceso de desestructuración del denominado régimen de cristiandad. ${ }^{8}$

Como ya hicimos referencia, nos centraremos en el estudio de la cofradía sacramental salteña en el período de la primera mitad del siglo XIX. Tal delimitación responde a los siguientes motivos. Fue en los albores del nuevo siglo cuando se hicieron sentir los primeros síntomas de decadencia en el funcionamiento cotidiano de la referida hermandad. Decadencia vinculada no sólo a un específico conjunto de factores internos, sino también a un contexto

5 Lempérière, "Orden corporativo y orden social. La reforma de las cofradías en la ciudad de México, siglos XVIII-XIX”, pp. 9-21.

6 Gudmunson, "La expropiación de los bienes de las obras pías en Costa Rica, 1805-1860: un capítulo en la consolidación económica de una elite nacional", pp. 37-92; González, "Desintegración de bienes de cofradías y de fondos píos en Costa Rica, 1805-1845", pp. 279-303; Arias Saavedra y López Muñoz, "Debate político y control estatal de las cofradías españolas en el siglo xvIII", pp. 423-435; Palomo Infante, "Tiempos de secularización: Iglesia y cofradías en Chiapas a partir de 1856", pp. 153-172; Carbajal López, "Las reformas de las cofradías en el siglo xviII: Nueva España y Sevilla en comparación”, pp. 3-33.

7 Quinteros, “Asociacionismo religioso. Cambios y permanencias en la transición del siglo XVIII al siglo XIX. Un estudio de caso. La cofradía Esclavitud del Santísimo Sacramento. Salta, Argentina, 1774-1880", pp. 329-343; Quinteros, "Profanando las sagradas fiestas con ritos y ceremonias gentilicias. Cofradías, poder y religiosidades. Salta, 1750-1810”, pp. 1-20.

8 Di Stefano, "¿De qué hablamos cuando decimos "Iglesia"? Reflexiones sobre el uso historiográfico de un término polisémico", pp. 197-222. 
de suma fragilidad institucional, política y eclesiástica, ${ }^{9}$ y a un escenario estremecido por las movilizaciones sociales, las guerras de la independencia y los constantes enfrentamientos internos.

La década de 1850 presenta, por su parte, sus propias particularidades; podemos considerarla una etapa bisagra entre un período signado por la movilización postindependentista ${ }^{10}$ e inestabilidad política (1810-1850) ${ }^{11}$ y otro que se concibió propicio para la consolidación de un nuevo proyecto político republicano y liberal. ${ }^{12}$ En el ámbito diocesano, el referido decenio, todavía caracterizado por la precariedad institucional, constituye la antesala de un tiempo de relativa prosperidad inaugurado por el gobierno de un nuevo obispo, Buenaventura Rizo Patrón. ${ }^{13}$ Como mencionamos ya, fue el transcurso de la década de 1850 cuando la cofradía del Santísimo Sacramento rozó su extinción. Los años siguientes, sin embargo, le depararán un nuevo auge, un renacimiento de la mano del laicado decimonónico.

El Libro de la cofradía del Santísimo Sacramento (1774-1856) constituye la principal fuente documental a partir de la cual hemos llevado a cabo nuestra investigación. Éste contiene los balances confeccionados por los mayordomos y administradores de la hermandad desde fines del período colonial hasta mediados del siglo XIX; un listado de asientos de cofrades; diversos inventarios de bienes; y algunas disposiciones de las autoridades eclesiásticas sobre los recursos cofradieros. Es éste también, cabe destacar, el registro más completo (y el único) que se ha conservado del conjunto de las cofradías religiosas que existieron en la ciudad Salta en el período ya señalado.

Nos resta, por último, antes de adentrarnos en nuestro análisis, explicitar qué entendemos por secularización. Siguiendo las consideraciones expuestas por Dobbelaere se trata de un fenómeno multidimensional que se desarrolla y verifica en diversos planos. La secularización es, por un lado, producto de la laicización de las instituciones sociales, es decir, de la emergencia de instituciones/esferas funcional y estructuralmente diferentes. En un segundo plano, alude a los procesos de modernización de la religión, a los cambios y transformaciones que ésta experimenta en calidad de ajustes al mundo moderno. Finalmente, la secularización se vincula con la pérdida de referencias religiosas en las conductas individuales y en las prácticas cotidianas de los miembros de

9 siglo $X X$.

10 Mata, "Conflicto y violencia en tiempos de crisis. Salta (Argentina) en las primeras décadas del siglo xix", pp. 33-54.

11 Figueroa, "Un huracán político el federalismo en el norte argentino en la primera mitad del siglo XIX", pp. 99-118.

12 Quintian, "Una aristocracia republicana. La formación de la elite salteña, 1850-1870".

13 Martínez, "Reforma ultramontana y disciplinamiento del clero parroquial. Diócesis de Salta 1860-1875", pp. 1-19. 
una comunidad. ${ }^{14}$ Son precisamente estas dos últimas nociones las que mejor parecen adaptarse para el análisis de los cambios que observaremos en el seno de la cofradía del Santísimo Sacramento en el tránsito del siglo XVIII al XIX.

\section{Cofradías y hermandades Religiosas. SAlta, PRimera mitad DEL SIGLO XIX}

La primera mitad del siglo xIx fue para las cofradías y hermandades religiosas de origen colonial un período de decadencia. Del conjunto de doce cofradías coloniales registradas en los diversos templos e iglesias de la ciudad de Salta, sólo seis lograron sobrevivir con distinta suerte hasta la década de 1860 . Algunas de éstas lo hicieron agónicamente. Entre ellas, como ya expusimos, la del Santísimo Sacramento, quizás una de las que gozó de mayor esplendor en las postrimerías del siglo XVIII y que en el transcurso de los años siguientes experimentó una notoria reducción de sus recursos, una disminución del número de sus miembros y una modificación en la composición de sus filas.

La suerte de las restantes no fue muy distinta. Así lo señalaba el informe elaborado por el Visitador Alurralde a principios de 1851, según el cual la cofradía de San Benito, con asiento en el Convento de San Francisco, funcionaba escasa de devotos; la de Nuestra Señora del Carmen, por su parte, alojada en la iglesia matriz, se encontraba diezmada institucionalmente ya casi sin recursos ni miembros. ${ }^{15}$

Varias son las posibles causas del deterioro de tales corporaciones en el transcurso de la primera mitad del siglo xIx. Una de ellas, las políticas impulsadas por los diferentes gobiernos y autoridades civiles con el fin de dar respuesta a sus necesidades económicas. Ya en el año de 1816 el gobernador salteño Martín Miguel de Güemes, amparado por las disposiciones instrumentadas por el Director Supremo de las Provincias Unidas del Río de la Plata, ordenó la expropiación de algunos recursos de cofradías. ${ }^{16}$ Años después, a principios de la década de 1830, tras la derrota de la Liga Unitaria de la que la provincia formó parte, el ejecutivo provincial implementó una política similar, "enajenando" bienes cofradieros para hacer frente a los costos de indemnización y reparación de impuestos por el victorioso caudillo federal Facundo Quiroga ${ }^{17}$ Los capitales expropiados en ambos casos fueron considerablemente exiguos. Sin embargo, en el marco de un declive general de las economías de las cofradías religiosas, significaron un duro revés para la supervivencia de éstas.

\footnotetext{
14 Dobbelaere, Secularización: un concepto multidimensional.

15 Visita Pastoral, Salta, 1851, Archivo Arzobispal de Salta (AAS), Carpeta Obispos.

16 Disposiciones de Gobierno, Salta, 1816, ABHS, Fondo de Gobierno, Carpeta 33.

17 Libro de la cofradía Esclavitud del Santísimo Sacramento, Salta, 1774-1859, ABHS.
} 
Esta necesidad de recursos impulsó también al ejecutivo provincial a sancionar la "Ley de enajenación de los bienes de obras pías y capellanías" en el año de $1831 .{ }^{18} \mathrm{Si}$ bien la medida tuvo escaso éxito, ${ }^{19}$ afectó a algunos bienes de cofradías destinados a la celebración del culto público, entre ellos, por ejemplo el que en su poder tenía, desde 1791, Ambrosio Fernández por valor de $\$ 1000^{20}$ con cuyos réditos se celebraba la fiesta del apóstol San Pedro. ${ }^{21}$ Desconocemos si tal festividad continuó celebrándose. Sin embargo, es probable que ya extinta la hermandad que la auspiciaba y sin garantías de que la Tesorería cumpliera con el pago de sus correspondientes intereses, la misma decayera aún más en el transcurso de los años siguientes.

Cabe destacar que en este contexto de relativo declive de las cofradías y hermandades religiosas emergieron nuevas formas asociativas, entre ellas la Sociedad de Beneficencia, la Sociedad Protectora de la Educación y la Sociedad Dramática. Tres asociaciones promovidas por los gobiernos federales de la década de 1830 y 1840 . Las dos primeras consagradas al estímulo de la educación de los habitantes de la ciudad, de las élites y de los sectores subalternos. La tercera orientada a la conformación de una instancia de crítica pública respecto de aquellos agentes que, como el clero, debían encargarse de la conducción de la sociedad. En este sentido, es posible observar una clara preferencia de las autoridades civiles por nuevas experiencias asociativas diferentes a las cofradías coloniales; es decir, por asociaciones modernas que, entre otros objetivos, bregaban por la "ilustración del pueblo salteño", instituidas al margen de la jurisdicción eclesiástica. A diferencia de las sociedades benéficas que cobraron vida en la vecina ciudad de Jujuy por estos mismos años, ${ }^{22}$ en Salta éstas, sin desprenderse planamente de los principios cristianos, tomaron otro rumbo, propiciando una mayor secularización de sus propósitos. ${ }^{23}$

Tales principios ilustrados devinieron en fundamento de otras medidas de gobierno que, tal como lo supieron hacer los borbones en las postrimerías del siglo XVIII, ${ }^{24}$ contemplaron la reforma de ciertas prácticas devotas. Entre ellas, aquellas que se propusieron disminuir el número de "fiestas religiosas entre

18 Decreto Enajenación de bienes raíces y obras pías, Salta, 1831, ABHS, Fondo de Gobierno, Leyes y decretos.

19 Levaggi, "La redención de capellanías en Salta en el periodo de 1831-1854", p. 169.

20 Informe del Obispo Ángel Mariano Moscoso, Salta, 1791, AAS, Carpeta Obispos.

21 Levaggi, "La redención de capellanías en Salta en el periodo de 1831-1854", p. 158.

22 Medina, "Entre lo terrenal y lo celestial. La Sociedades de Beneficencia y Filantrópicas de Jujuy: concepciones ideológicas y proyectos (siglo XIX)", pp. 173-199.

23 Quinteros, "Asociaciones, beneficencia, educación y teatro. Salta, primera mitad del siglo XIX”, pp. 11-40.

24 Carbajal López, "La reforma de las cofradías novohispanas en perspectiva comparada: procedimientos, definiciones y alcances, 1750-1820", pp. 325-350. 
semana" que servían más (según la percepción de las autoridades civiles) al fomento de los vicios que al de la industria, la sana moral, la civilización y del mismo catolicismo. ${ }^{25}$ Es posible pensar también que las normativas de este tenor operaron en detrimento de cofradías y hermandades sobre las que recaía la celebración del culto público.

Amén de lo expuesto, creemos que la decadencia de las cofradías religiosas fue el resultado, sobre todo, de las modificaciones que se produjeron en las mismas prácticas asociativas de una parte de la feligresía. Fenómeno también observado para otras latitudes rioplatenses ya hacia finales del siglo XVIII. ${ }^{26}$ Las escasas fuentes disponibles para el período analizado no nos permiten dar respuestas más acabadas para el caso salteño. La documentación correspondiente a la segunda mitad del siglo xIX da cuenta, sin embargo, de un efectivo proceso de popularización que experimentaron las cofradías decimonónicas de origen colonial producto del alejamiento del componente masculino de la élite; un rasgo que se convirtió en una marca perenne y definitiva. El distanciamiento de uno de los grupos más dinámicos y prósperos que supo tradicionalmente administrar y dirigir a estas cofradías y hacerse cargo de sus principales funciones religiosas repercutió negativamente en el funcionamiento de éstas.

\section{La cofradía Esclavitud del Santísimo Sacramento}

Instituido en el año de 1264 por el Papa Urbano IV y promovido a mediados del siglo Xvi por el Concilio de Trento, el Corpus Christi se convirtió en una de las principales festividades del mundo católico; máxima expresión del triunfo de la fe contra la herejía protestante que negaba la presencia real del Cuerpo de Cristo en la Sagrada Forma. Ampliamente difundido en los reinos españoles, el culto eucarístico se trasladó al nuevo mundo de la mano de los primeros colonizadores, conservando, mediante la fastuosidad propia de la sensibilidad barroca, su función pedagógica ante los devotos de los más variados escenarios. $^{27}$ En ambos lados del Atlántico surgieron también numerosas corporaciones religiosas que se consagraron a su exaltación. En algunas de las ciudades más periféricas del virreinato del Perú, fue principalmente en el período comprendido entre fines del siglo XVI y mediados del XVII cuando se instituyeron las primeras cofradías, hermandades y esclavonías sacramentales;

25 Comunicación remitida por el gobernador de la provincia al Provisor y Vicario Capitular de la Diócesis de Salta, Salta, 1850. AAS, Carpeta Asociaciones.

26 Di Stefano, "Orígenes del movimiento asociativo: de las cofradías coloniales al auge mutualista", p. 40. Fogelman, "Una cofradía mariana urbana y otra rural en Buenos Aires a fines del período colonial”, pp. 26-27.

27 Garavaglia, "Del Corpus a los toros: fiesta, ritual y sociedad en el río de la plata colonial", pp. 391-419. 
en Buenos Aires en 1596, en Salta en 1627, en Córdoba en 1628 y en Jujuy en 1656, es decir, al poco tiempo de sus respectivas fundaciones, poniendo en evidencia la vinculación entre las directrices de la Iglesia católica y las necesidades espirituales de los primitivos moradores de los poblados españoles. ${ }^{28}$

El establecimiento de la cofradía Esclavitud del Santísimo Sacramento en la iglesia matriz de Salta fue un acto promovido por los cabildantes y el cura párroco, quienes redactaron sus estatutos en presencia del delegado del Obispo del Paraguay. Fueron estas autoridades, civiles y eclesiásticas, las encargadas de garantizar, de forma conjunta, la prosperidad de la corporación.

Ya desde sus inicios la hermandad nucleó en su seno a numerosos representantes del grupo de los beneméritos propietarios de tierra. Entre ellos los miembros de las familias Arias Rengel, Díaz Zambrano, Porcel de Peralta, Aguirre y Medina Pomar que hasta la primera mitad del siglo XVIII dominaron la escena política. ${ }^{29}$ No se trató, sin embargo, de una cofradía de exclusivo carácter elitista, pues podían integrarla (y de hecho lo hicieron, aunque de forma minoritaria) los naturales y algunos pobres de la ciudad con la condición de pagar un abono menor o brindar algún servicio. Contaba también la cofradía con el servicio de algunos negros esclavos de su propiedad, adquiridos por el beneficio de diversos legados testamentarios, a los cuales se les procuraba enseñar algún instrumento musical para reducir el costo de las funciones religiosas.

Durante el período colonial la cofradía se nutrió, de igual forma, de hombres y mujeres, observándose un relativo equilibrio entre ambos. No obstante, las responsabilidades de unos y otros fueron distintas. El ejercicio de los cargos directivos fue prerrogativa masculina; a las cofradas, por su parte, les correspondió ocuparse del adorno y decoración de la iglesia matriz, de la compostura de las flores, las velas y los altares en las vísperas y transcurso de las jornadas festivas.

Hacia fines del siglo XVIII el arribo a la ciudad de prósperos comerciantes dará nuevo impulso a la hermandad sacramental; sus filas se robustecerán de este dinámico grupo que, además, desempeñará un papel clave en la gestión y administración de los recursos cofradieros. ${ }^{30}$

28 Núñez y Ruiz-Díaz, "La Archicofradía del Santísimo Sacramento de la Catedral de Buenos Aires (siglos XVI al XVIII)", pp. 301-356; Estruch, "Fundar, gobernar y rezar. Una aproximación a los vínculos entre sociedad, política y religión en el Jujuy colonial. 16651776)", pp. 61-78; Martínez de Sánchez, Cofradias y Obras pías en Córdoba del Tucumán, p. 76 .

29 Marchionni, Marcelo (1999), "Una elite consolidada. El cabildo de Salta en tiempo de cambios", pp. 181-182.

30 Libro de la cofradía Esclavitud del Santísimo Sacramento, Salta, 1774-1859, ABHS. 


\section{Jurisdicción y autoridades}

Hacia fines del siglo XVIII los borbones acentuaron su control sobre el funcionamiento de cofradías y hermandades religiosas, emprendiendo un plan general de reformas mediante el cual se propusieron, entre otros objetivos, sujetarlas a su autoridad en detrimento de la eclesiástica. ${ }^{31}$ Estas medidas (sintomáticas de lo que algunos autores han denominado una primera y mayor instancia de secularización o "secularización borbónica") ${ }^{32}$ se materializaron de forma diferencial en la península y en las más diversas latitudes de la América española. En Sevilla, por ejemplo, los funcionarios representantes de la Corona incrementaron su poder en los cabildos cofradieros desplazando así al clero; en Nueva España estos últimos sólo perdieron su título de presidentes de dichas juntas en beneficio de los jueces reales. ${ }^{33}$ En la ciudad de Córdoba del Tucumán también se efectivizó la presencia de tales ministros en las reuniones de cofrades. ${ }^{34}$

Para el espacio salteño no disponemos de las fuentes documentales suficientes para sopesar los alcances efectivos de tales medidas. Las órdenes dispuestas por el obispo Ángel Mariano Moscoso en su visita pastoral del año de 1791, sin embargo, dan cuenta del creciente poder del clero en la regulación de estas corporaciones aun en el marco de las reformas mencionadas, tal vez incluso, como parte de ellas y/o de su particular materialización en el escenario local. Y aún más, según detallaba el prelado, los capítulos anuales de las cofradías con asiento en la iglesia matriz (principales instancias de gobierno y de deliberación de los destinos de tales corporaciones) donde debían intervenir los representantes de la Corona con el fin de ejercer control sobre las mismas, apenas se celebraban. ${ }^{35}$ Lo que también operó en beneficio de la jurisdicción eclesiástica y las prerrogativas del clero sobre el conjunto de las cofradías y hermandades salteñas.

El cabildo, por su parte, concentraba diversas prerrogativas. Debía refrendar las elecciones de mayordomos de cofradías tradicionalmente efectuadas por las autoridades eclesiásticas; contribuir con limosnas y aportes pecuniarios al realce y decoro de las funciones religiosas; ${ }^{36}$ y participar de tales celebraciones

31 Carbajal López, David, 2012.

32 Lempérière, "Orden corporativo y orden social. La reforma de las cofradías en la ciudad de México, siglos XVIII-XIX", p. 20; Di Stefano, "Por una historia de la secularización y la laicidad en la Argentina", pp. 4-5.

33 Carbajal López, "Las reformas de las cofradías en el siglo XVIII: Nueva España y Sevilla en comparación".

34 Martínez de Sánchez, Cofradias y obras pías en Córdoba del Tucumán, Córdoba, p. 87.

35 Informe del Obispo Ángel Mariano Moscoso, Salta, 1791, AAS, Carpeta Obispos.

36 Libro de la cofradía Esclavitud del Santísimo Sacramento, Salta, 1774-1859, ABHS. 
que, amén de sus propósitos espirituales, contribuían a la edificación del vecindario $^{37} \mathrm{y}$ al sostenimiento y reproducción del orden social. ${ }^{38}$

En líneas generales esta particular distribución de responsabilidades se mantuvo hasta mediados de la década de 1820. En el específico caso de la cofradía del Santísimo Sacramento, todavía por aquellos años sus directivos eran personajes vinculados al gobierno civil por el ejercicio de diversos cargos en el ayuntamiento de la ciudad. Todavía, también, los aportes de recursos por parte de las autoridades civiles para la fiesta del Corpus eran regulares. Ya desde fines del decenio de 1820, sin embargo, la injerencia del poder temporal en el gobierno y en el funcionamiento cotidiano de la corporación sacramental se redujo notoriamente, pasando ésta a depender, casi de forma exclusiva, del control del clero salteño. Esta nueva situación, cabe destacar, no les impidió a las élites dirigentes avanzar sobre los bienes cofradieros en determinadas coyunturas, tal como las que referenciamos líneas atrás, sobre todo para hacer frente a ciertas exigencias económicas.

Durante la primera mitad del siglo XIX, como en el período precedente, la dirección de la hermandad sacramental continuará siendo una labor correspondiente a agentes laicos. Desde 1813 a 1817 la mayordomía recayó en Luis Refojos, pulpero perteneciente a los sectores sociales medios. $\mathrm{Su}$ nombramiento como tal reviste algunas particularidades respecto a la de sus predecesores coloniales. En primer lugar, porque Refojos no formaba parte de los sectores más conspicuos de la ciudad. Su carrera ascendente en el escenario local careció del lustre que caracterizó a las trayectorias de los comerciantes que supieron ejercer dicho oficio en las postrimerías del período colonial. ${ }^{39}$ Sin tierras ni fortuna, su principal bien lo constituyó una pulpería dedicada principalmente a la venta de efectos de Castilla. ${ }^{40}$

En segundo lugar, y relacionado con lo anterior, porque Refojos desempeñó primeramente el cargo de diputado de la hermandad para luego recién asumir su mayordomía. Sus predecesores coloniales, por el contrario, exitosos comerciantes provenientes de península y de otras jurisdicciones de la América española, fueron designados oficialmente en el cargo sin más méritos que el "celo y devoción" que las autoridades civiles y eclesiásticas parecían reconocer en ellos. ${ }^{41}$ Refojos, quizás por no pertenecer al selecto círculo de

37 Nota del mayordomo de la cofradía de Nuestra Señora del Rosario al Cabildo de la ciudad, Salta, 1795. AAS, Carpeta Asociaciones.

38 Chaile, Devociones religiosas, procesos de identidad y relaciones de poder en Salta. Desde la colonia hasta principios del siglo $\mathrm{XX}$, p. 152.

39 Quinteros, “Asociacionismo religioso. Cambios y permanencias en la transición del siglo XVIII al siglo xIX. Un estudio de caso. La cofradía Esclavitud del Santísimo Sacramento. Salta, Argentina, 1774-1880”, pp. 332-333.

40 Testamento Luis Refojos, Salta, 1818, ABHS, Testamentarias.

41 Libro de la cofradía Esclavitud del Santísimo Sacramento, Salta, 1774-1859, ABHS. 
la élite local, carecía, de buenas a primeras, de tales credenciales por lo que debió atravesar un camino distinto, es decir cumplir con otras exigencias para finalmente acceder al principal cargo de gobierno cofradiero reservado para los laicos.

Así la designación de Refojos podría constituir el primer síntoma de un lento, pero progresivo proceso de depreciación de la importancia relativa de los cargos directivos de la cofradía, es decir, de su consideración como una variable de prestigio para quienes tradicionalmente habían hecho uso de él. El lugar social del referido pulpero, como un efecto de lugar, ${ }^{42}$ se inscribió en el cargo de mayordomo que supo ejercer por un lustro, disminuyendo el valor de éste, pues al volverse asequible a aquellos que se encontraban al margen del selecto círculo nobiliar perdió la exclusividad que antaño lo había caracterizado.

Es posible vincular este fenómeno a un contexto signado por las convulsiones de la guerra de la independencia que afectaron el normal funcionamiento de la institución. Convulsiones que en parte también explican, por un lado, el cese de las actividades de la cofradía y su acefalia directiva durante el período comprendido entre febrero de 1812 y mayo de 1813. Por otro, la notable disminución del ingreso de nuevos miembros durante la gestión de Refojos (uno por año) en relación con los ingresos registrados a finales del período colonial. ${ }^{43}$ En efecto, a partir del decenio de 1810 empezarán a expresarse tímidamente las primeras modificaciones en la fisonomía de la hermandad; en la disponibilidad de sus recursos; en la composición y número de sus miembros; y en sus formas administrativas. La mayordomía de Refojos, con la excepcionalidad de su trayectoria y posición social, pareció inaugurar así una nueva etapa cuyos caracteres sólo se revertirán promediando la década de 1860 , ya en un contexto distinto.

Entre 1818 y 1848 la cofradía quedó en manos de la familia González de Hoyos, propietaria de algunas tierras ${ }^{44}$ Durante este período, la dirección de la hermandad funcionó como una suerte de empresa familiar dirigida primeramente por Hermenegildo González de Hoyos (1818-1827), por su hijo Camilo (1828-1843) y su esposa Isabel Ruiz de los Llanos (1844-1848). Con Hermenegildo la corporación quedó en manos de un personaje bien posicionado en la esfera política salteña durante la década de 1810 y parte del decenio siguiente. Contaba éste además con algunos importantes vínculos sociales. ${ }^{45}$ Tras su muerte, sin embargo, su familia no logró sostener parte de

Bourdieu, Efectos de lugar, pp. 119-124.

Libro de la cofradía Esclavitud del Santísimo Sacramento, Salta, 1774-1859, ABHS.

Marchionni, "Una elite consolidada. El cabildo de Salta en tiempo de cambios", p. 202.

Entre las relaciones más ventajosas Hermenegildo Hoyos cabe destacar a Juan Antonio

Álvarez de Arenales, militar de destacada participación en las guerras de la independencia y 
su modesto prestigio, perdiendo incluso protagonismo político en el transcurso del decenio de 1830.

Con la gestión de la familia González de Hoyos al frente de la hermandad operó un proceso de patrimonialización de los cargos cofradieros de gobierno, es decir, su conversión en una exclusiva responsabilidad familiar, propiciando consecuentemente la eliminación de la competencia por el mismo. Dicho de otra manera; el escaso interés que parecía despertar en los miembros de la élite el ejercicio de un oficio de cofradía (otrora variable de prestigio), ${ }^{46}$ permitió que el mismo deviniera en prerrogativa de una sola familia.

A este fenómeno contribuyeron dos procesos estrechamente relacionados: la popularización de su composición social y el marcado incremento del número de mujeres entre sus filas. En efecto, las figuras más prominentes del ámbito político y económico, el componente masculino de la élite no formaba ya parte de ella. Se produjo así una notable disminución de los cofrades con las credenciales sociales necesarias de entre quienes las autoridades de la ciudad y de la diócesis pudieran elegir a su mayordomo; actores sociales para quienes tradicionalmente este oficio se había reservado. Dicha patrimonialización operó también en detrimento de la designación del mayordomo de la cofradía como instancia de reconocimiento social; en detrimento de la oportunidad de expresar simbólicamente el lugar social del ungido ante los miembros de la comunidad. De hecho, ni Camilo González de Hoyos ni su madre Isabel Ruiz de los Llanos gozaron de tal beneficio. Ambos asumieron la dirección de la hermandad sin la mediación de alguna jornada festiva. Y más aún. Lo hicieron sin recibir el título de mayordomo, sólo en calidad de "administradores". ${ }^{47}$ Así, la muerte de Hermenegildo en el año de 1827 marcará el inicio del período de una extensa vacante del que fuera el cargo más importante de la cofradía, el del mayordomo, reemplazado interinamente por el de "administrador", desprovisto este último de algún tipo de atractivo que ameritara la competencia entre los miembros la nueva élite posrevolucionaria.

Pero quizás la máxima expresión de los cambios que por entonces operaban en la esfera de gobierno de la cofradía fue la asunción de una mujer como principal responsable de su dirección. Al igual que con Luis Refojos algunos años atrás, la gestión de Isabel Ruiz de los Llanos puede concebirse como el síntoma de una efectiva depreciación de los oficios cofradieros en la medida

gobernador de la provincia entre 1824 y 1827, casado con María Josefa González de Hoyos, hermana de Hermenegildo; y Evaristo Uriburu, acaudalado comerciante con una importante trayectoria política como presidente de la legislatura local y como gobernador delegado en diversas oportunidades.

46 Quinteros, "Asociacionismo religioso. Cambios y permanencias en la transición del siglo XVIII al siglo XIX. Un estudio de caso. La cofradía Esclavitud del Santísimo Sacramento. Salta, Argentina, 1774-1880", pp. 332-333.

47 Libro de la cofradía Esclavitud del Santísimo Sacramento, Salta, 1774-1859, ABHS. 
en que dichos agentes ocupaban un lugar subordinado en las estructuras de relaciones de poder. La asunción de Isabel puede percibirse como una variable de la desvalorización general de la asociación en tanto espacio de sociabilidad religiosa y como espacio de lucha y de competencia por el poder ${ }^{48}$ para el componente masculino de la élite local.

El monopolio de la mayordomía de la hermandad en manos de agentes laicos durante la primera mitad del siglo XIX (al igual que en el período precedente) más que vincularse a un proyecto secularizador decimonónico emprendido por los propios cofrades y/o las autoridades civiles fue probablemente el resultado de un tácito acuerdo entre todas las partes involucradas en el funcionamiento de la asociación sacramental. De hecho, el clero conservó su cuota de poder durante todo el período analizado, sujetando al mayordomo a su jurisdicción, controlando todos y cada uno de sus actos. Y ello, amén del interés por el sostenimiento del culto eucarístico, porque los fondos de ésta, aunque escasos (compuestos por los aportes de su feligresía y, sobre todo, por los de la familia Hoyos), se constituyeron en una suerte de reserva para los canónigos, diáconos y sacristanes que celebraban y solemnizaban los oficios sagrados en un período de tiempo en el que las rentas eclesiásticas se revelaron exiguas. ${ }^{49}$

Hacia el año de 1848, luego de más de medio siglo de dirección seglar, el presbítero Gabriel Díaz asumirá el cargo de mayordomo de la asociación, iniciando de esta forma una modalidad de gestión que se caracterizó por la concentración de dicho oficio y el de capellán en un representante del clero. A partir de entonces fueron los agentes eclesiásticos los encargados de atender los asuntos mundanos y espirituales de la cofradía y sus miembros, experimentando así la asociación un efectivo proceso de clericalización. Lejos de suscitar algún tipo de conflicto, esta modificación fue el resultado natural, por un lado, de la progresiva deserción del componente masculino de la élite local de las filas de la hermandad y, sobre todo, de su desinterés por dirigirla; por otro, de un proceso de reorganización institucional en clave romana que operó, ya promediando la centuria, en el seno de la propia de la Iglesia.

\section{Composición}

Durante la primera mitad del siglo xix la composición de la cofradía experimentó una serie de profundas transformaciones que propiciaron la mutación de su carácter. Se hizo evidente, en primer lugar, una sensible disminución del número de sus socios. Entre 1774 y 1810 se registró la inscripción de 386 personas; entre 1811 y 1859 la cifra total de inscriptos menguó a 225 miembros. Del primer al segundo período el porcentaje de inscripciones anuales se

48 Bourdieu, Pierre, La dominación masculina, pp. 66-67.

49 Bruno, Historia de la Iglesia en la Argentina, pp. 517-532. 
redujo, de esta manera, de 10 a 6 . Se observa, además, en el segundo lapso, una notoria preeminencia de la modalidad de asiento individual en detrimento de la grupal. Este último factor nos permite pensar que la reducción de sus miembros fue aún más drástica pues la modalidad grupal, predominante en el período colonial, implicó generalmente la inscripción de un titular (el padre de familia) y, de forma automática, la de su cónyuge y sus hijos. Su registro en el libro de la cofradía, sin embargo, sólo da cuenta del nombre del primero y el de su esposa, manteniendo incierto el número de sus vástagos y demás agregados que también habitaban la "casa", lo que dificulta considerablemente su contabilización.

Una segunda modificación importante operó de forma simultánea a la ya señalada; el relativo equilibrio de género que caracterizó la cofradía sacramental en las postrimerías del período colonial fue cediendo a un notable predominio femenino. Entre 1774 y 1813 hemos podido registrar el asiento de 196 mujeres y 201 hombres; entre 1814 y 1858, la balanza se inclinó a favor de las primeras alcanzando el número de 124 asientos, duplicando a los segundos.

La disminución general del número de cofrades y el incremento del número de mujeres respecto a los hombres fueron fenómenos que se complementaron con el notorio aumento de las mujeres de los sectores medios y pobres de la sociedad salteña en las filas de la hermandad; mujeres que se registraron generalmente pagando un estipendio menor al estipulado constitucionalmente y/o con la condición de brindar algún servicio o "servir en cuanto se ofrezca al Santísimo". El componente femenino de la élite (a diferencia de sus pares masculinos) conservó una significativa representación, aun cuando minoritaria ya de entre el conjunto de cofradas.

En las postrimerías de la primera mitad del siglo XIX, la cofradía sacramental de la iglesia matriz de la ciudad había adquirido ya algunos de los rasgos que la definirán en el siguiente período; una asociación con un acentuado perfil femenino que aunó en su seno a las mujeres de los diversos grupos sociales que poblaban la ciudad.

Si analizamos en detalle las referidas variables que propiciaron la mutación del carácter de la cofradía del Santísimo Sacramento, obtendremos algunas consideraciones interesantes respecto de las modificaciones que se produjeron en las prácticas religiosas de la feligresía local y, en relación con ello, a las características que asumió el proceso de secularización en el transcurso de la primera mitad del siglo XIX.

La reducción del número total de sus miembros podría constituir un claro indicio (como mencionamos en líneas anteriores) de la disminución de la importancia relativa de la asociación en tanto espacio de sociabilidad, máxime si tenemos en cuenta que, durante el período en cuestión, no se conformaron otras asociaciones religiosas de este tipo que le disputaran la adscripción de 
los miembros de la comunidad. Esta reducción de sus filas se correspondió entonces con el declive general que experimentaron las cofradías religiosas salteñas en la transición del siglo XVIII al XIX, y que, en diversos casos, provocó la extinción de algunas de ellas.

Las causas de este fenómeno general aún no son del todo claras y podrían ser diversas. Es probable que, como sucediera en la ciudad de Buenos Aires, su decadencia se vinculara con la paulatina pérdida de sentido de representaciones y prácticas religiosas relacionadas con la buena muerte que estas asociaciones tanto se preocupaban por alcanzar. ${ }^{50}$ Sin alejarnos demasiado de nuestro escenario, en la vecina ciudad de Jujuy, ya a partir de la década de 1820, es posible observar la progresiva configuración de una nueva sensibilidad religiosa que al expresarse críticamente sobre el lugar de entierro de los cuerpos difuntos lo hacía también sobre las acciones que jalonaban la carrera por la salvación de sus almas. ${ }^{51}$

Tales principios propios de una nueva "piedad ilustrada", presentes también ya desde fines del siglo XVIII en la plaza salteña, ${ }^{52}$ pudieron propiciar algunas modificaciones en la religiosidad de la feligresía local, en sus expresiones y en sus niveles de compromiso con las asociaciones cultuales como las cofradías y hermandades religiosas encargadas de brindar servicios de entierro y gracias e indulgencias para la salvación de las almas de los devotos.

En lo que respecta a la composición sexo-genérica de la asociación, se destaca el proceso de feminización que operó en la misma; proceso que se expresó tímidamente hasta la década de 1830 para consolidarse en el decenio siguiente y constituirse en uno de sus rasgos más sobresaliente de la segunda mitad del siglo XIX. La feminización de las filas de la cofradía sacramental preanuncia un fenómeno que caracterizará al asociativismo católico moderno impulsado con gran vigor por el laicado decimonónico a partir de la década de 1860 ya con el apoyo del obispo Buenaventura Rizo Patrón.

Tal fenómeno puede concebirse también como expresión del proceso de secularización en tanto da cuenta de la autonomía que las prácticas asociativas masculinas fueron adquiriendo respecto a la autoridad religiosa, más precisamente respecto al clero que regulaba y controlaba los ejercicios fraternos espirituales. El alejamiento de los hombres supone también el abandono de esos mismos ejercicios vinculados a la celebración del culto religioso y a la

50 Di Stefano, Di Stefano, “Orígenes del movimiento asociativo: de las cofradías coloniales al auge mutualista", p. 41.

51 Geres, "Con el muerto a otra parte... Consideraciones sobre la piedad mortuoria y sus espacios en la ciudad de Jujuy entre fines de la colonia y los primeros años independientes", pp. 95-114.

52 Chaile, Devociones religiosas, procesos de identidad y relaciones de poder en Salta. Desde la colonia hasta principios del siglo XX, pp. 197-202. 
provisión de gracias e indulgencias para la salvación del alma en el "más allá". Durante la década de 1840 y 1850 surgirán en la ciudad de Salta diversas asociaciones conformadas por los miembros de la élite local, orientadas al teatro, al ocio, a la lectura y al divertimento. Su emergencia no sólo dará cuenta de una cada vez más definida decimonónica división sexual del trabajo social, sino también del interés de los conspicuos por conformar espacios modernos de sociabilidad situados más allá de la jurisdicción eclesiástica, al margen del poder del clero que por entonces se convertía en blanco de numerosas críticas. ${ }^{53}$

Ahora bien, ello no necesariamente debe interpretarse como una manifestación de irreligiosidad de los notables salteños. Más parecería vincularse, por el contrario, a un proceso de reformulación de sus aptitudes sociales y de género y a una redefinición de las formas mediante las cuales expresaban su religiosidad y sus niveles de compromiso para con sus referentes sagrados. Procesos que bien pueden comprenderse como constitutivos de la modernidad religiosa, una de las variables de la reconfiguración del hecho religioso. ${ }^{54} \mathrm{El}$ componente masculino de un incipiente laicado decimonónico sostuvo de diferentes maneras su vínculo con la religión a través, por ejemplo, de aportes pecuniarios que permitían costear las fiestas religiosas, de la defensa del catolicismo desde las esferas de gobierno y de su explícita adhesión a las manifestaciones públicas de fe en detrimento del constante apostolado que propugnaban las corporaciones de origen colonial como las cofradías.

En función a los cambios aludidos la cofradía sacramental flexibilizó, durante la primera mitad del siglo XIX, los requerimientos de ingreso de sus devotos. Las mujeres, a diferencia del período precedente, adoptaron la práctica de inscribirse en la asociación de forma individual, en calidad de titulares de sus asientos, ya sin la necesidad de contar con el acompañamiento de sus esposos.

Su registro se ajustó así a su voluntad individual en detrimento de las formas y modalidades corporativas y grupales propias de la colonia. ${ }^{55}$

Las cofradas, además de superar significativamente a sus pares masculinos, adquirieron (por ello mismo) un mayor protagonismo en los preparativos del culto público que se celebraba en honor a la "Sagrada Forma". Eximidas tradicionalmente de las funciones de gobierno, fueron las principales responsables del lucimiento de la referida festividad encargándose de las

\footnotetext{
53 Quinteros, "Asociaciones, beneficencia, educación y teatro. Salta, primera mitad del siglo XIX".

54 Mínguez Blasco, "Monjas, esposas y madres católicas: una panorámica de la feminización de la religión en España a mediados del siglo xIX”; Mínguez Blasco, “¿Dios cambió de sexo? El debate internacional sobre la feminización de la religión y algunas reflexiones para la España decimonónica", pp. 397-426.

55 Di Stefano, "Orígenes del movimiento asociativo: de las cofradías coloniales al auge mutualista", p. 34.
} 
tareas de adorno y decoración de la iglesia matriz; de la compostura de las flores y los altares. Algunas incluso ingresaban a la hermandad con el explícito fin de consagrarse como "esclavas del Santísimo" y servir así "en todo lo concerniente al culto divino", 56 entre ellas "las betas" responsables de labrar la cera de las velas e hilar su pabilo para alumbrar la función religiosa y de realizar las compras de yerba y azúcar para el convite de los asistentes a la jornada festiva.

Para muchas cofradas estas labores no eran diferentes a las que desempeñaban desde el recinto doméstico. De hecho, es posible observar una efectiva continuidad de tales tareas religiosas desde el hogar a la iglesia impulsada por un ideario que se impuso con renovada fuerza en el transcurso del siglo XIX según el cual existía un estrecho vínculo entre religión y mujer ${ }^{57}$ que otorgaba a esta última un rol protagónico en el sostenimiento del culto (privado y público $)^{58}$ y la difusión de los principios evangélicos. ${ }^{59}$ Estas representaciones, como principios históricos de organización de las diferencias sexuales, ${ }^{60}$ legitimaban, por un lado, las actividades femeninas que, realizadas en el seno del mismo hogar, se orientaban, entre otros fines, al cuidado de los oratorios, la vestimenta de sagradas imágenes y su traslado y visita por los altares vecinos; y las que, trascendiendo el recinto doméstico, se llevaban a cabo en los templos para la celebración de diversas funciones públicas.

La continuidad a la que nos referimos entre una esfera más íntima y otra más pública se observa también en el tratamiento de la salud y la enfermedad, otra práctica de profundo sentido religioso en el que las mujeres desempeñaron un rol protagónico ${ }^{61}$ ya en el seno de sus mismos hogares, de otros ajenos ${ }^{62}$ y en el hospital de la ciudad. ${ }^{63}$ Conforme transcurrió el siglo XIX, el sostenimiento del culto y el cuidado del cuerpo y del alma (labores inscritas en el terreno de los espiritual) se concibieron y se constituyeron como actividades femeninas por excelencia, vehiculizadas y canalizadas, sobre todo a partir de la década de 1860, por un variado conjunto de asociaciones católicas impulsadas por

56 Libro de la Cofradía Esclavitud del Santísimo Sacramento, Salta, 1773-1859, ABHS.

57 Narea Aresti, "El ángel del hogar y sus demonios. Ciencia, religión y género en la España del siglo XIX”, 363-394.

58 Beeche, De Salta a Cobija. Cartas de Gregoria Beeche de Garcia a sus hijos (1848-1867).

59 Reflexiones religiosas y sociales que en obsequio que en obsequio de la religión y la República hace Escolástico Zegada, Salta, 1856, AAS.

60 Blasco Inmaculada, "Género y religión: de la feminización de la religión a la movilización católica femenina. Una revisión crítica”, Historia Social, núm. 53, 2005, pp. 123.

${ }_{61}$ Chaile, "Promesas y prácticas curativas de devotos "a nombre de" la Virgen María y de Cristo en el Noroeste argentino en el transcurso del siglo XIX al xx", p. 461.

62 Frías, Tradiciones Históricas, p. 574.

63 Quinteros, "Mujeres, beneficencia y religiosidad. un estudio de caso. salta, segunda mitad del siglo XIX (1864-1895)". 
el componente más activo y dinámico del laicado decimonónico salteño: las mujeres.

En este escenario se produjo otra importante modificación. La asunción de Isabel Ruiz de los Llanos como "administradora" de la hermandad cuya gestión marcó el fin de un extenso período que se remonta a inicios de la época colonial y que se caracterizó por el continuo desempeño de la mayordomía de la asociación por agentes laicos masculinos. Será ella la última directiva seglar que se encargará de la administración de los recursos cofradieros. Tras su breve gestión (1844-1848) dicha tarea se convertirá en una prerrogativa clerical, manteniéndose así hasta principios del siglo xx.

La administración de Isabel Ruiz de los Llanos constituye una experiencia excepcional e inédita en la larga trayectoria de la cofradía sacramental; inconcebible para el pensamiento ilustrado dieciochesco que bregaba por una incorporación y participación más bien limitada de las mujeres en el seno de tales corporaciones ${ }^{64}$ y contraria a la configuración institucional de las cofradías salteñas decimonónicas que se caracterizaron por reservar sus principales cargos de gobierno para los hombres, aun cuando la mayoría de éstas tuviera un marcado carácter femenino. Cabe destacar que la gestión de Isabel Ruiz de los Llanos, tal como las anteriores, también estuvo sujeta al control del vicario de la diócesis de Salta encargado de revisar los balances que ésta confeccionaba anualmente; balances que antes de ser presentados eran refrendados por Camilo, su hijo.

Desconocemos los motivos por los que Isabel asumió como administradora de la asociación. Es probable que, tras veinte años de gestión, Camilo (su hijo) decidiera apartarse finalmente del cargo, delegándoselo a un familiar directo, su madre. Cualquiera haya sido la causa, contó de igual manera con la autorización y aprobación de las máximas autoridades de la diócesis que debieron flexibilizar los tradicionales principios de funcionamiento de la hermandad en respuesta, quizás, a la profunda crisis que experimentaba por entonces la asociación, sobre todo por la falta de compromiso de los escasos hombres que la conformaban. No fue casual, por ello, que su asunción se produjera en un momento de extrema fragilidad económica para la cofradía, casi al borde de su extinción y reducida su actividad tan sólo a la celebración de la fiesta del Corpus, jornada carente ya de toda solemnidad y lustre; es decir, en un período de tiempo en el que se encontraba completamente desvalorada por una comunidad urbana que supo hacer de ella, otrora, una resplandeciente corporación.

Nos corresponde ahora abordar el análisis de las modificaciones que se produjeron en la composición social de la cofradía del Santísimo Sacramento.

64 Carbajal López, "Devoción, utilidad y distinción. La reforma de las cofradías novohispanas y el culto del Santísimo Sacramento, 1750-1820”, pp. 377-389. 
Hicimos ya referencia a la configuración de una moderna piedad que tomó distancia de algunas de las representaciones vinculadas al "buen morir" y que pareció tener mayor asidero en las élites rioplatenses (más que en otros grupos sociales) propiciando el abandono de las filas de las asociaciones de este tipo.

Para los sectores de menor poder, quizás más ajenos a tales premisas, las cofradías continuaron conformando, aunque sin el esplendor de antes, espacios a través de los cuales pudieron asegurarse algunos servicios funerarios. Pudieron también tales hermandades constituirse, como lo habían hecho ya a fines del período colonial, en una de sus pocas instancias de cohesión e integración social formalmente aceptadas por las autoridades civiles y eclesiásticas de la ciudad cada vez más preocupadas, conforme transcurrió la primera mitad del siglo XIX, en ejercer un mayor control sobre las "sospechosas" prácticas de sociabilidad de los grupos subalternos. ${ }^{65}$

La mayor parte de ellos ingresó a la cofradía sin pagar el estipendio de cuatro pesos establecidos constitucionalmente, con la sola condición de brindar algún servicio. Las mujeres, como ya hicimos referencia, podían por ejemplo preparar las velas para el alumbrado del Corpus. Los hombres, costear su ingreso en calidad de músicos, de orfebres y/o asumiendo el compromiso de recorrer las calles de la ciudad recolectando las limosnas. Un caso paradigmático es el de José Dionisio Blasco y de Manuel Alemán que pagaron su ingreso a cambio de "tocar el violín en todas las misas y celebraciones de la iglesia matriz". Y no sólo eso, por su dedicación durante varios lustros, ambos recibieron también una paga, pues a pesar de los escasos recursos con los que contaba la asociación, la familia Hoyos no prescindió de los servicios de los músicos. Otros se asociaron simplemente pagando un importe menor o a cambio de algunos productos como jabón, entre ellos; Braulia Santos, negra liberta, de oficio pulpera; Marcelino Sarapura, carnicero analfabeto que se asentó junto a su esposa, (Marcelina Martearena, panadera); o Dionisio Olarte, sastre de profesión. Todos ellos, abonando tan sólo la suma de dos pesos, esperando beneficiarse de las considerables y numerosas gracias e indulgencias que la cofradía les ofrecía. ${ }^{66}$

\section{Bienes, economía y culto}

Los cambios mencionados líneas atrás repercutieron decisivamente en la economía de la hermandad sacramental. La disminución de sus miembros y el incremento de la modalidad de asiento sin el pago del estipendio estipulado redujeron de forma considerable los recursos disponibles para la celebración

65 Raspi, "Sobre tenderos y pulperos: minoristas urbanos de Salta y Jujuy (siglo XIX)", pp. 3233.

66 Libro de la Cofradía Esclavitud del Santísimo Sacramento, Salta, 1773-1859, ABHS. 
de la festividad del Corpus y el cumplimiento de las misas por los cofrades vivos y difuntos a partir de la década de 1820. Desde entonces los ingresos (que en período colonial permitieron afrontar los gastos cotidianos con relativa holgura) se revelaron insuficientes por lo que el sostenimiento de las actividades cofradieras dependió, casi de forma exclusiva, de los aportes de sus mayordomos.

En el período comprendido entre 1813 y 1817 la situación de la cofradía era todavía estable. Las limosnas recolectadas por las calles de la ciudad eran suficientes para costear las misas de renovación y las celebradas por el aniversario de los cofrades difuntos; el trabajo de artesanos (plateros algunos de ellos) para las composiciones de adornos y alhajas; y la compra de suntuosos enseres ${ }^{67}$ Contaba además la hermandad, hasta entonces, con nutrido repositorio de bienes; cálices y vinajeras de oro; faroles, esquilones y cazoletas de plata; finas alfombras, cortinas, banderas de tafetán y bandas guarnecidas de oropel. No faltaban los animales; varios caballos con los que se pedía la limosna y treinta mulas criadas y alimentadas en los potrerillos de algunos miembros de la hermandad.

A los sacerdotes que participaban en los santos oficios, la cofradía se encargaba de proveerlos de casullas de glasé, de tisú de oro y de brocato; de albas de coco calado, de cíngulos de cinta de raso y de sotanillas. ${ }^{68}$ Durante la fiesta del Corpus, la Sagrada Forma prosesionaba por los alrededores del templo todavía con cierto decoro, portada por una custodia grande de plata, resguardada por vistosos palios cuyas varas lucían incrustados adornos de plata. ${ }^{69}$ Sin embargo, esa relativa estabilidad posrevolucionaria bien pronto empezó a dar cuenta de su debilidad.

Los balances efectuados por la familia González de Hoyos en el período comprendido entre 1818 y 1848 dan cuenta de un pronunciado declive de los ingresos de la hermandad. Durante dicho lapso los gastos superaron los ingresos anuales, debiendo sus directivos costear los excesos con sus particulares recursos. Estos últimos oscilaron entre los $\$ 3$ y los $\$ 400$ que destinaron principalmente al pago de los servicios provistos por el clero, los músicos y cantores para la función del Corpus, además de la cera para su alumbrado.

La situación era ya bastante crítica para el año de 1824 cuando, con el objeto de resguardar los exiguos recursos de la hermandad sacramental, el Vicario Capitular de la diócesis, Gabriel de Figueroa, ordenó que no se pagaran las misas de renovación, las que deberían en adelante celebrarse voluntariamente

\footnotetext{
67 Libro de la Cofradía Esclavitud del Santísimo Sacramento, Salta, 1773-1859, ABHS, Administración de Luis Refojos.

68 Libro de la Cofradía Esclavitud del Santísimo Sacramento, Salta, 1773-1859, ABHS, Inventarios de bienes.

69 Ibid.
} 
por los religiosos de la iglesia matriz; que no se comprasen nuevos utensilios; y que se redujera el acostumbrado uso de la cera para el alumbramiento del octavario del Corpus. ${ }^{70}$

Tales disposiciones, sin embargo, no tendrán efecto en la diezmada economía. Apenas algunos años más tarde, promediando la década de 1830, las actividades de la cofradía, antaño extendidas anualmente de principio a fin, se habían reducido únicamente a la recolección de limosnas y a una cada vez más austera (cuando no pobrísima) celebración, en el mes de junio, de la festividad eucarística. Fue también en el primer lustro del decenio de 1830 cuando las autoridades civiles procedieron a la enajenación de algunos de los bienes de la asociación tal como ya hicimos referencia. Aun cuando sólo pudo afectarse un raquítico patrimonio (principalmente utensilios de culto cuyo valor apenas alcanzó el importe de \$40), la intervención significó un duro revés en el marco de la crisis general que la afectaba. Durante el transcurso de las décadas siguientes la situación económica de la cofradía no prosperó. Por el contrario, los males que la aquejaban, todavía a principios de 1860, parecían amenazarla de muerte, sin poder siquiera contar con los recursos necesarios para celebrar su función principal. ${ }^{71} \mathrm{Su}$ estado decadente no era excepcional, pues, como ya expusimos, la mayoría de estas asociaciones acusaban algunos síntomas de considerable fragilidad.

Para comprender el paulatino proceso de deterioro económico de estas experiencias asociativas, resulta menester considerar también el impacto que tuvieron (o pudieron tener) diversas medidas adoptadas por los sucesivos gobiernos civiles en el transcurso de la primera mitad del siglo xIx; medidas que afectaron a los bienes de la iglesia y sus corporaciones como ya hicimos referencia líneas atrás. Cabe aclarar, sin embargo, que no se trató de una empresa llevada a cabo por funcionarios civiles adversarios a este tipo de experiencias asociativas, por el contrario, algunos de los que intervinieron en ella, como el Ministro de Hacienda, Pedro Antonio Ceballos y Pintos, eran cofrades de algunas de estas hermandades.

\section{CONSIDERACIONES FINALES}

El tránsito del Antiguo Régimen a la Modernidad implicó resolver la cuestión de la redefinición del lugar de las instituciones eclesiásticas en un nuevo orden político de horizontes inciertos aún por aquellos años. La paulatina, pero finalmente certera, transformación de una relación de "simbiosis" a una de 
“emulsión" que operó entre la esfera civil y la religiosa ${ }^{72}$ contempló además la crisis de algunas de las formas mediante las cuales el catolicismo se imbricaba con la sociedad, es decir, se fundía con las comunidades de antiguo cuño.

No fueron éstas, sin embargo, transformaciones radicales, unívocas, ni lineales respecto al orden precedente. Durante largo tiempo convivieron en el escenario salteño, como en otras ciudades, elementos de una piedad barroca con los de una piedad ilustrada. ${ }^{73}$ Incluso el orden político que empezó a gestarse tras la revolución de 1810 encontró algunos de sus fundamentos en antiguos principios y prácticas, resignificados bajo nuevos postulados jurídicos, dotándose así de mayor legitimidad. Y en esta empresa, la religión, sus símbolos y festividades, el mismo clero y su púlpito desempeñaron un papel crucial. ${ }^{74}$

En este marco, la trayectoria decimonónica de la cofradía del Santísimo Sacramento nos permite comprender algunos aspectos de las relaciones que mediaron entre los diferentes gobiernos independientes y la Iglesia católica en el período posrevolucionario. Debemos señalar que la relación entre ambos poderes durante el transcurso de buena parte del siglo XIX estuvo marcada, principalmente, por las urgencias de la coyuntura más que por las directrices de un proyecto acabado. El poder temporal fue, de manera progresiva, desatendiendo sus tradicionales obligaciones para con la que fuera una de las más antiguas e importantes cofradías coloniales. Muy desdibujado quedó, sobre todo a partir de la segunda mitad de la década de 1820, el rol de "patrono" que supo desempeñar tiempo atrás. ${ }^{75}$ Sus aportes monetarios para la cofradía sacramental fueron cada vez más escasos; nula su intervención en la dirección de éstas. Su antiguo protagonismo decayó conforme la asociación perdió su importancia en el seno de la comunidad salteña.

Desde el punto de vista económico, entonces, lejos estuvo la hermandad sacramental de beneficiarse por los aportes de las autoridades civiles. Por el contrario, como pudimos analizar, ésta sufrió la expropiación de algunos de sus pocos bienes ya en la década de 1830 . Tal medida no respondió a un específico plan de reformas; las cofradías no parecieron representar ningún obstáculo para la libre circulación de recursos pues casi que no contaban en su haber con los denominados "bienes espiritualizados". Fueron las urgencias de

72 Peire, El taller de los espejos. Iglesia e imaginario, 1767-1815, pp. 191-199.

73 Peire, El taller de los espejos. Iglesia e imaginario, 1767-1815, pp. 180-184. Chaile, Devociones religiosas, procesos de identidad y relaciones de poder en Salta. Desde la colonia hasta principios del siglo XX, pp. 197-202.

74 Caretta y Marchionni, "Entre la ciudadanía y la feligresía. Una cuestión de poder en Salta a principios del siglo XIX”, pp. 1-25; Barral y Binetti, "Las formas de la religiosidad católica: algunos desplazamientos en la primera mitad del siglo XIX", pp. 84-85.

75 Libro de la Cofradía Esclavitud del Santísimo Sacramento, Salta, 1773-1859, ABHS. 
las arcas provinciales más bien las que, a partir de 1820, marcaron la relación entre el poder temporal y los recursos cofradieros.

Durante la primera mitad del siglo XIX las élites dirigentes se ocuparon por fomentar y promocionar otras experiencias asociativas en detrimento de las cofradías y hermandades religiosas. Entre ellas las asociaciones de beneficencia, que parecían adecuarse mejor a los intereses del nuevo proyecto político puesto en marcha. A diferencia de las cofradías coloniales, compuestas por los sectores subalternos de la ciudad, estas nuevas experiencias asociativas se conformaron como espacios particularmente elitistas; instancias asociativas desde las cuales los notables sancionaron diferencias y distancias concretas respecto a los que se encontraban al margen de su selecto círculo.

Para la Iglesia Católica el sostenimiento de la cofradía sacramental le significó un duro desafío. En el período comprendido entre 1810 y 1850 una crisis general marcó la existencia de las hermandades religiosas de la ciudad. Creemos que esta situación bien se corresponde con los males propios de una diócesis endeble, sin recursos humanos y materiales para hacer frente a las necesidades de un vasto territorio. En este contexto, las medidas instrumentadas por el clero para hacer frente a una experiencia asociativa en declive tuvieron nulo efecto. Incluso luego de 1848, tras finalizar el largo período de gestión de la familia González de Hoyos, poco pudieron hacer los curas de la iglesia matriz por la recuperación de la hermandad sacramental ya al borde del abismo. No contaban por entonces con los aportes particulares de la referida familia que le había permitido a la corporación cumplir con algunos (los menos) de sus fines. Tampoco contaba ya, promediando la década de 1860, con las limosnas de sus fieles, pues éstos, lentamente, habían abandonado sus filas.

En este escenario operó una progresiva clericalización de la hermandad sacramental que se expresó, entre otros factores, en la concentración del cargo de mayordomo y el de capellán en un miembro del clero; en una mayor sujeción de éstos a los designios del obispo de la diócesis; y en la conversión de la asociación en una suerte de junta de fábrica de la iglesia matriz, tal como también se ha observado para otros espacios, ${ }^{76}$ confundiendo incluso sus propios recursos con aquellos destinados al sostenimiento de dicho templo. ${ }^{77}$

Tal proceso, que se verificó de manera general en el conjunto de cofradías religiosas conformadas ya durante la segunda mitad del siglo XIX, puede comprenderse, en el caso específico de la asociación sacramental, como una posible respuesta a las urgencias coyunturales del momento; la ausencia entre sus filas de los hombres con las credenciales necesarias para asumir su dirección. De hecho, durante el período colonial, el clero tomó en sus manos, en diversas

Serrano, "Espacio público y espacio religioso en Chile republicano", pp. 350-351.

Nota del capellán de la cofradía del Santísimo Sacramento, Gabriel Díaz, al Vicario Capitular de la diócesis, Isidoro Fernández, Salta, 1863, AAS, Carpeta Asociaciones. 
oportunidades, dicha prerrogativa, sobre todo cuando las irregularidades de las administraciones seglares lo ameritaron. ${ }^{78}$ Hacia mediados del siglo XIX, en un escenario diferente, fue esta una alternativa definitiva, más que aleatoria, que bien se ajustó a los designios del proyecto de romanización que por entonces tomaba fuerza. ${ }^{79}$

En este sentido es posible reconocer una de las variables del proceso de secularización según la propuesta analítica de Dobbelaere; las transformaciones que experimentó la religión al objeto de adaptarse a las condiciones impuestas por la modernidad. La clericalización a la que nos referimos da cuenta de cambios específicos en las estructuras organizativas de estas asociaciones; cambios que serán recogidos y sancionados por las constituciones de cofradías redactadas en el transcurso de la segunda mitad del siglo xx y que operaran en procura de la definición de nuevas formas de gobierno y nuevos principios administrativos.

Por otra parte, las transformaciones que se verificaron en la composición en el seno de la hermandad sacramental pueden leerse como otra de las dimensiones de la secularización propuesta por el referido autor; con la pérdida de referencias religiosas en las conductas individuales y en las prácticas cotidianas de los miembros de una comunidad. La crisis de la hermandad sacramental fue producto de su abandono por parte de algunos miembros de la sociedad local; en líneas generales, del componente masculino de la feligresía; y particularmente, de los hombres de la élite posiblemente impulsados por nuevas formas de religiosidad.

El alejamiento de los hombres da cuenta también de la disminución de la importancia relativa de la hermandad en tanto espacio de poder. La pérdida del decoro de la fiesta del Corpus implicó la pérdida de una tradicional instancia de construcción ritual del poder social; la extinción de uno de los objetivos del denominado "consumo de prestigio" o estatus. Es probable también que el expresado comportamiento masculino de la élite local se viera influenciado por la difusión de una moderna crítica religiosa que se ceñía sobre el clero y su indisciplina. Sujetas a las autoridades eclesiásticas, las cofradías pudieron sufrir los efectos de tales ideas, perdiendo incluso su atracción como espacio de sociabilidad. Lo expuesto nos permite afirmar que el componente masculino de la élite local, en el transcurso de la primera mitad del siglo XIX, prescindió de los servicios espirituales y simbólicos de la cofradía, o mejor dicho, se los encomendó a las mujeres de sus familias. Por el contrario, este sector social pareció encontrar mayor atractivo en otras experiencias asociativas; sociedades teatrales, educativas y recreativas, desprovistas de la injerencia

78 Informe del Obispo Ángel Mariano Moscoso, Salta, 1791, AAS, Carpeta Obispos.

79 Lida, "Secularización: doctrina, teoría y mito. Un debate desde la historia sobre un viejo tópico de la sociología", pp. 43-63. 
del clero. Incluso el mismo Tribunal Mercantil fundado en el transcurso de la década $1820^{80}$ pudo constituir un nuevo espacio de sociabilidad para algunos de los comerciantes más prósperos de la ciudad, entre ellos los descendientes de quienes se desempeñaron como mayordomos de la cofradía sacramental a fines del período colonial.

Debemos también ensayar una hipótesis ante la deserción de los hombres de los sectores populares. Para ellos también quizás las representaciones acerca del "más allá" fueron perdiendo importancia en el transcurso del siglo XIX. Motivo que pudo complementarse con otro; las particularidades de la configuración institucional de la hermandad sacramental que reservó sus cargos directivos sólo para algunos actores sociales. Los sectores populares tuvieron pocas posibilidades de injerir en la dirección de ésta. La gestión de Luis Refojos se presenta así como una excepcionalidad inédita, no como el producto de una política institucional perenne de apertura social.

Resulta menester ahora señalar algunas consideraciones respecto al perfil femenino que fue adquiriendo la asociación ya en el transcurso de la primera mitad del siglo xIx. Fue éste un fenómeno paulatino (aunque finalmente definitivo) que debe matizarse con el fin de valorarlo en su justa medida, pues se produjo en el marco del declive general de la hermandad y de la misma disminución del número de mujeres respecto de los asientos registrados en las postrimerías del siglo XVIII. En este contexto, la preeminencia de las cofradas se comprende, en parte, por la redefinición de las representaciones de género que operó en el transcurso del siglo xix; proceso por el cual, en la división sexual del trabajo social la figura de la mujer se sujetó al ámbito de lo espiritual, de lo religioso y las actividades inherentes a esta esfera (como los preparativos del culto). En este mismo terreno espiritual se anclaron las labores femeninas orientadas a la cura del cuerpo y el alma. Hacia fines de la década de 1840 emergió la primera asociación femenina dedicada a la atención del recientemente fundado Hospital del Señor y la Virgen del Milagro, establecimiento dirigido por el clérigo Isidoro Fernández. Sostenemos que el conjunto de estas actividades empezó a pensarse y concebirse ya en el transcurso de la primera mitad del siglo XIX como tareas propiamente femeninas legitimando así su traspolación desde el recinto doméstico a los templos y a los establecimientos de moralización y disciplinamiento como los hospitales decimonónicos. Desde estos espacios fue cobrando protagonismo el papel de las mujeres como principales responsables en una economía de salvación, ${ }^{81}$ mediante la atención del culto público y el cuidado de los enfermos.

$80 \quad$ Morillo, "Elites, redes mercantiles y tribunal de comercio en Salta durante la primera mitad del siglo XIX", pp. 41-58.

81 Fogelman, “Una 'economía espiritual de la salvación'. Culpabilidad, purgatorio y acumulación de indulgencias en la era colonial”, pp. 1-26. 
Amén de las motivaciones religiosas que pudieron impulsar estas prácticas, resulta menester considerar que para las mujeres salteñas del temprano siglo XIX, vedadas de participar, de manera general, de otras experiencias asociativas y círculos culturales e intelectuales, la cofradía del Santísimo Sacramento constituyó uno de sus principales espacios de sociabilidad.

Como sostuvimos ya, la preeminencia de las mujeres en las filas de la hermandad sacramental anticipa un fenómeno que se generalizará en la segunda mitad del siglo XIX imprimiéndole al asociacionismo católico salteño un perfil marcadamente femenino. Creemos que este proceso como tal se encuentra estrechamente ligado a la secularización y a la relación entre religión y modernidad por cuanto nos permite observar algunas de las modificaciones que operaron en las prácticas de la feligresía decimonónica y advertir las posibles respuestas ensayadas por la iglesia católica ante dichos cambios.

\section{Bibliografía}

Arias de Saavedra, Inmaculada y López Muñoz, Miguel Luis, "Debate político y control estatal de las cofradías españolas en el siglo XviII", Bulletin Hispanique, núm. 99, 1997, pp. 423-435. DOI: https://doi.org/10.3406/hispa.1997.4948

Barral, María Elena, "Iglesia, poder y parentesco en el mundo rural colonial. La cofradía de Ánimas benditas del Purgatorio, Pilar. 1774”, Colección Cuadernos de Trabajos, núm. 10, 1998, pp. 15-56.

Barral y Binetti, "Las formas de la religiosidad católica: algunos desplazamientos en la primera mitad del siglo xIx", en Valentina Ayrolo, Elena Barral y Roberto Di Stefano (Coords.), Catolicismo y secularización. Argentina, primera mitad del siglo XIX, Buenos Aires, Biblos, pp. 67-91.

Beeche, Gregoria, De Salta a Cobija. Cartas de Gregoria Beeche de García a sus hijos (1848-1867), Buenos Aires, Fundación Nicolás García Uriburu, 2008.

Blasco Inmaculada, "Género y religión: de la feminización de la religión a la movilización católica femenina. Una revisión crítica”, Historia Social, núm. 53, 2005, pp. 119-136.

Bourdieu, Pierre, La dominación masculina, Barcelona, Anagrama, 2000, pp. 66-67.

Bourdieu, Pierre (Dir.), "Efectos de lugar", La miseria del mundo, Buenos Aires, Fondo de Cultura Económica, 2007, pp. 119-124.

Bruno, Cayetano, Historia de la Iglesia en la Argentina, vol. 9, Buenos Aires, Don Bosco, 1974.

Carbajal, David, "Las reformas de las cofradías en el siglo XviII: Nueva España y Sevilla en comparación”, Estudios de Historia Novohispana, núm. 48, 2012, pp. 3-33. https://doi.org/10.22201/iih.24486922e.2013.048.38577

Carbajal López, David, "La reforma de las cofradías novohispanas en perspectiva comparada: procedimientos, definiciones y alcances, 1750-1820”, en María del Pilar Martínez López-Cano y Francisco Javier Cervantes Bello (Coords.), Reformas y resistencias en la Iglesia novohispana, México, Universidad Nacional Autónoma de México, 2014, pp. 325-350. 
Carbajal López, "Devoción, utilidad y distinción. La reforma de las cofradías novohispanas y el culto del Santísimo Sacramento, 1750-1820", Hispania Sacra, vol. 68, núm. 137, 2016, pp. 377-389. https://doi.org/10.3989/hs.2016.025

Caretta, Gabriela y Marchionni, Marcelo, "Entre la ciudadanía y la feligresía. Una cuestión de poder en Salta a principios del siglo XIX”, Andes, núm. 11, 2000, pp. $1-25$.

Caretta Gabriela y Zacca Isabel, "Benditos ancestros: comunidad, poder y cofradía en Humahuaca en el siglo XVIII”, Boletín Americanista, núm. 62, 2011, pp. 51-72.

Cirio, Norberto Pablo, “¿Rezan o bailan? Disputas en torno a la devoción a San Baltazar por los negros en el Buenos Aires colonial”, en Víctor Rendón (Ed.), Mujeres, negros y niños en la música y sociedad colonial Iberoamericana, Asociación Pro Arte y Cultura, Santa Cruz de la Sierra, 2002, pp. 88-100.

Cruz, Enrique Normando, "Autoridades socio-religiosas en el antiguo régimen. Las mayordomos de cofradías en el Jujuy colonial”, Cuadernos del Sur, Universidad Nacional del Sur, vols. 30-31, 2002, pp. 35-56.

Cruz, Enrique Normando, "Esclavos españoles, indios y negros: notas para el estudio de las relaciones interétnicas en las cofradías religiosas del norte del Virreinato del Río de la Plata", Boletim do Museu Paraense Emílio Goeldi. Ciências Humanas, vol. 8, núm. 2, 2013, pp. 449-458.

Chaile, Telma, Devociones religiosas, procesos de identidad y relaciones de poder en Salta. Desde la colonia hasta principios del siglo $x x$, Salta, CAPACIT-AR, 2011.

Chaile, Telma, "Promesas y prácticas curativas de devotos "a nombre de" la Virgen María y de Cristo en el Noroeste argentino en el transcurso del siglo XIX al xx", Historia, núm. 50, pp. 443-470. https://doi.org/10.4067/s0717-71942017000200443

Di Stefano, Roberto, "Por una historia de la secularización y de la laicidad en la Argentina", Quinto Sol, vol. 15, núm. 1, 2011, pp. 1-30. https://doi.org/10.19137/qs.v15i1.116

Di Stefano, Roberto, “¿De qué hablamos cuando decimos "Iglesia”? Reflexiones sobre el uso historiográfico de un término polisémico", Ariadna histórica. Lenguajes, conceptos, metáforas, núm. 1, 2012, pp. 197-222.

Di Stefano, Roberto, "Orígenes del movimiento asociativo: de las cofradías coloniales al auge mutualista", en Elba Luna y Élida Cecconi (Coords.), De las cofradías a las organizaciones de la sociedad civil. Historia de la iniciativa asociativa en la Argentina, 1776-1990, Buenos Aires, Edilab, 2002, pp. 25-99.

Di Stefano, Roberto y Zanatta, Loris, Historia de la iglesia argentina. Desde la conquista hasta fines del siglo XX, Buenos Aires, Sudamérica, 2009.

Dobbelaere, Karel, Secularización: un concepto multidimensional, México, Universidad Iberoamericana, 1994.

Estruch, Dolores, "Fundar, gobernar y rezar. Una aproximación a los vínculos entre sociedad, política y religión en el Jujuy colonial. 1665-1776)", Runa, vol. 30, núm. 1, 2009, pp. 61-78.

Figueroa, Eulalia, "Un huracán político. El federalismo en el norte argentino en la primera mitad del siglo XIX", Cuadernos FHyCS-UNJu, núm. 21, 2003, pp. 99-118. 
Fogelman, Patricia, "Una cofradía mariana urbana y otra rural en Buenos Aires a fines del período colonial”, Andes, núm. 11, 2000, pp. 179-207.

Fogelman, Patricia, "Una "economía espiritual de la salvación". Culpabilidad, purgatorio y acumulación de indulgencias en la era colonial", Andes, núm. 15, 2004, pp. 1-26.

Frías, Bernardo, Tradiciones Históricas, Salta, Fondo editorial, 2013.

Garavaglia, Juan Carlos, "Del Corpus a los toros: fiesta, ritual y sociedad en el río de la plata colonial", Anuario IEHS, núm. 16, 2002, pp. 391-419.

Geres, René Osvaldo, "Con el muerto a otra parte... Consideraciones sobre la piedad mortuoria y sus espacios en la ciudad de Jujuy entre fines de la colonia y los primeros años independientes", Andes, núm. 21, 2010, pp. 95-114.

González Bernaldo, Pilar, "La revolución francesa y la emergencia de nuevas prácticas de la política: la irrupción de la sociabilidad política en el Río de la Plata revolucionario (1810-1815)", Boletín del Instituto de Historia Argentina y Americana, núm. 3, 1991, pp. 7-27.

González Fasani, Mónica, “¿Qué entendemos por cofradía colonial?: una aproximación a un marco teórico para su estudio", en Hilda Raquel Zapico (Coord.) De prácticas, comportamientos y formas de representación social en Buenos Aires (siglos XVII-XIX), Bahía Blanca, Universidad Nacional del Sur, pp. 225-259.

González García, Yamilet, "Desintegración de bienes de cofradías y de fondos píos en Costa Rica, 1805-1845”, Mesoamérica, núm. 5, 1984, pp. 279-303.

Gudmundson, Lowell, "La expropiación de los bienes de las obras pías en Costa Rica, 1805-1860: Un capítulo en la consolidación económica de una élite nacional”, Revista de Historia, núm. 7, 1978, pp. 37-92.

Lempériére, Annick, "Orden corporativo y orden social. La reforma de las cofradías en la ciudad de México, siglos XVIII-XIX”, Historia y Sociedad, núm. 14, 2008, pp. 9-21.

Levaggi, Abelardo, "La redención de capellanías en Salta en el período de 1831-1854", Boletín del Instituto de San Felipe y Santiago de Estudios Históricos, núm. 38, 1985, pp. 153-172.

Lida, Miranda, "Secularización: doctrina, teoría y mito. Un debate desde la historia sobre un viejo tópico de la sociología", Cuadernos de Historia, Serie Economía y Sociedad, núm. 9, 2007, pp. 43-63.

Marchionni, Marcelo, "Una élite consolidada. El cabildo de Salta en tiempo de cambios" en Sara Mata de López (Comp.), Persistencias y cambios: Salta y el noroeste argentino. 1779-1840, Rosario, Prohistoria \& Manuel Suárez, 1999, pp. 177-217.

Marchionni, Marcelo, “Acceso y permanencia de las élites en el poder político local. El cabildo de Salta a fines del período colonial”, Cuadernos FHyCS-UNJu, núm. 13, 2000, pp. 281-304.

Martínez de Sánchez, Ana María, Cofradías y obras pías en Córdoba del Tucumán, Córdoba, Editorial de la Universidad Católica de Córdoba, 2006.

Martínez, Ignacio, "Reforma ultramontana y disciplinamiento del clero parroquial. Diócesis de Salta 1860-1875”, Andes, vol. 2, núm. 28, 2017, pp. 1-19. 
Mata, Sara Emilia, "Conflicto y violencia en tiempos de crisis. Salta (Argentina) en las primeras décadas del siglo XIX”, Secuencia, núm. 90, 2014, pp. 33-54. https://doi.org/10.18234/secuencia.v0i90.1236

Mazzoni, "Cofradías como zona de contacto. Diócesis de Córdoba, fines del siglo XVIII y principios del xix", en Ana Laura Lanteri (Comp.) Actores e identidades en la construcción del estado nacional (Argentina, siglo XIX), Buenos Aires, Teseo, 2013, pp. 97-127.

Medina, "Entre lo terrenal y lo celestial. La Sociedades de Beneficencia y Filantrópicas de Jujuy: concepciones ideológicas y proyectos (siglo XIX)", Folia histórica, núm. 23, 2015, pp. 173-199. https://doi.org/10.30972/fhn.02346

Mínguez Blasco, Raúl, "Monjas, esposas y madres católicas: una panorámica de la feminización de la religión en España a mediados del siglo XIX", Amnis, 2012. https://doi.org/10.4000/amnis.1606

Mínguez Blasco, Raúl, “¿Dios cambió de sexo? El debate internacional sobre la feminización de la religión y algunas reflexiones para la España decimonónica”, Historia contemporánea, núm. 51, 2015, pp. 397-426. https://doi.org/10.1387/hc. 14714

Morillo, Elizabeth, "Élites, redes mercantiles y tribunal de comercio en Salta durante la primera mitad del siglo XIX", Cuaderno de la facultad de Humanidades y Ciencias Sociales, núm. 21, 2003, pp. 41-58.

Narea Aresti, Esteban, "El ángel del hogar y sus demonios. Ciencia, religión y género en la España del siglo XIX”, Historia contemporánea, núm. 21, 2000, pp. 363394.

Núñez y Ruiz-Díaz, Sergio Rodolfo, "La Archicofradía del Santísimo Sacramento de la Catedral de Buenos Aires (siglos XVI al XviII)", Revista Cruz del Sur, núm. 14, 2015, pp. 301-356.

Palomo Infante, María Dolores, "Tiempos de secularización: iglesia y cofradías en Chiapas a partir de 1856", Mesoamérica, núm. 46, 2004, pp. 153-172.

Peire, Jaime, El taller de los espejos. Iglesia e imaginario, 1767-1815, Buenos Aires, Claridad, 2000.

Quinteros, Enrique, "Mujeres, beneficencia y religiosidad. Un estudio de caso. Salta, segunda mitad del siglo XIX (1864-1895)", Andes, núm. 28, 2017, pp. 1-26.

Quinteros, Enrique, "Asociacionismo religioso. Cambios y permanencias en la transición del siglo XVIII al siglo XIX. Un estudio de caso. La cofradía Esclavitud del Santísimo Sacramento. Salta, Argentina, 1774-1880", Hispania Sacra, núm. 143, 2019, pp. 329-343. https://doi.org/10.3989/hs.2019.024

Quinteros, Enrique, "Profanando las sagradas fiestas con ritos y ceremonias gentilicias. Cofradías, poder y religiosidades. Salta, 1750-1810”, Quinto Sol, vol. 22, núm. 2, 2018, pp. 1-20. https://doi.org/10.19137/qs.v22i2.1935

Quinteros, "Asociaciones, beneficencia, educación y teatro. Salta, primera mitad del siglo xIx”, Procesos, núm.51, 2020, pp. 11-40.

Quintian, Juan, "Una aristocracia republicana. La formación de la élite salteña, 18501870", Tesis Doctoral, Universidad de San Andrés, Buenos Aires, 2012.

Raspi, Emma, "Sobre tenderos y pulperos: minoristas urbanos de Salta y Jujuy (siglo XIX)", Cuadernos FHyCS-UNJu, núm. 21, 2003, pp. 23-39. 
Serrano, Sol, "Espacio público y espacio religioso en Chile republicano", Teología y Vida, vol. XLIV, 2003, pp. 346-355.

https://doi.org/10.4067/S0049-34492003000200015

Vagliente, Pablo, "El asociativismo comparado: Buenos Aires y Córdoba en la etapa de la explosión asociativa 1850-1890", en II Jornadas de Historia e Integración Cultural del Cono Sur, Facultad de Humanidades, Artes y Ciencias Sociales de la Universidad Autónoma de Entre Ríos, 2005, pp. 1-14.

Zanolli, Carlos, "Entre la coerción, la oportunidad y la salvación. Las cofradías de indios de San Antonio de Humahuaca. Siglos XVII y XVIII", Andes, núm. 19, 2008, pp. 345-369. 